\title{
Chief executives' approval of immigrants: Evidence from a survey experiment of 101 Latin American and Caribbean mayors
}

\author{
Claudia N. Avellaneda*, Johabed G. Olvera*
}

\begin{abstract}
Several countries worldwide have experienced increasing immigration waves. Studies have explained immigration attitudes mainly in terms of cultural threats and material self-interest. However, scarce attention has been given to chief executives' empathy toward the causes of migration, the impact of which may be moderated by the size of the migration wave. We test these propositions on data drawn from a surveyexperiment using 101 Latin American and Caribbean mayors as subjects. Mayors were presented with hypothetical situations in which they had to approve or reject an experimentally manipulated number of immigrants. The cause of their migration was also manipulated by randomly presenting mayors a number of immigrants due to either an earthquake (natural disaster), a civil conflict, or an unspecified cause (control group). Findings show 79 percent of mayors approved immigrants regardless of the cause. Mayors are more likely to approve immigrants when the migration cause is stated. However, mayoral approval of immigrants due to disasters is not statistically different from mayoral approval of immigrants due to civil conflict. When the size of the immigration wave increases, mayors are still more likely to accept immigrants due to natural disasters, but less likely to accept immigrants due to civil conflict. Interestingly, South American, Caribbean and Central American mayors tend to be more empathetic toward immigrants than their Mexican colleagues.
\end{abstract}

Keywords: Immigrants, Latin American and Caribbean Mayors, Survey experiment, Decision making

$\mathrm{I}_{\mathrm{r} \text { tam }}$ n recent decades, several countries have experienced increasing immigration waves. Some have fled their countries due to natural disasters, civil conflict, pandemics, food shortages, human rights violations, and/or water scarcity. Immigration waves can be triggered by external shocks (e.g., natural disasters, weather conditions) and government-controlled factors (e.g., civil conflict, human rights violations, pandemics), leading us to ask if migration's cause influences chief executives' decisions to accept immigrants.

Existing literature has mainly focused on explaining people's attitudes toward immigrants. This line of research has highlighted the role of ideology (Joppke, 1998), cultural threats (Chandler \& Tsai, 2001; Card et al., 2012), materialistic self-interest (Citrin et. al., 1997; Esses et. al., 1998), national identity (Huddy, 2001; Sniderman et. al.,

\footnotetext{
* School of Public and Environmental Affairs, Indiana University

Address correspondence to Claudia Avellaneda at (cavellan@indiana.edu)

Copyright: (C) 2018. The authors license this article under the terms of the Creative Commons Attribution 4.0 International License.
}

2004), perception about ethnic groups, and perceived knowledge of immigrant population size (Nadeau et. al., 1993; Sides \& Citrin, 2007). However, scarce attention has been given to chief executives' empathy toward causes of migration. Leaders' empathy towards immigrants may vary, as leaders might be more sensitive toward one cause. We expect leaders would be more empathetic toward immigrants who fled due to natural disasters than civil conflicts, as leaders may (1) perceive natural disasters to be outside of government control, and (2) understand the situation, given their prospects of experiencing the same crisis. However, the impact of immigration cause on leaders' approval of immigrants may be moderated by the size of the migration wave.

By focusing on actual chief executives' approval of immigrants, this survey-experiment differs from existing studies. Most existing studies have relied on citizens' opinions about immigration (Bansak et al., 2016; see Hainmmueller \& Hopkins, 2014 for a review of 100 studies). Although mayors' approval might be based on citizens' and interest groups' attitudes towards immigrants, ultimately, 
chief executives decide. For instance, despite several interest groups' disapproval of President Trump's ban against some immigrants, his tough stance toward immigrants has not rendered. Surprisingly, leaders' approval of immigrants has mainly been explained in terms of leaders' political ideology, leaving other potential factors unexplored.

We tested our propositions on data drawn from a survey-experiment whose subjects were 101 Latin American and Caribbean mayors. Although general acceptance of immigrants occurs at the national/cabinet level, mayors are responsible for integration strategies, services delivery and for dealing with intended or unintended consequences of immigration decisions. Moreover, mayors may convey their own experiences with immigration to higher-level officials, which may affect the officials' future acceptance decisions. In this study, mayors were presented with hypothetical situations in which they had to decide whether to approve or reject an experimentally manipulated number of immigrants. In addition, the cause of their migration was manipulated by randomly presenting mayors a number of immigrants due to an earthquake (natural disaster), a civil conflict, or an unspecified cause (control group).

This research contributes to the literature on immigration attitudes and decision-making in the realm of behavioral public administration. In particular, this study adds to our understanding of factors influencing municipal chief executives' decision-making regarding immigration issues. Results indicate that Latin American and Caribbean chief executives tend to be empathetic toward immigrants. Findings show 79 percent of mayors approved immigrants, regardless of the cause. Mayors are more likely to approve immigrants when the migration cause is stated. However, mayoral approval of immigrants due to disasters is not statistically different from mayoral approval of immigrants due to civil conflict. When the immigration wave increases, mayors are still more likely to accept immigrants due to natural disasters, but less likely to accept immigrants due to civil conflict. Interestingly, South American, Caribbean and Central American mayors tend to be more empathetic toward immigrants than their Mexican colleagues. We provide some theoretical speculations for this finding.

\section{Literature Review}

Increasing waves of immigrants into both developed and developing countries have triggered research addressing natives' attitudes toward immigrants. Hainmueller \& Hopkins (2014) classify this existing research into two categories: 1) works explaining attitudes toward immigration relying on broader socio-psychological approaches, and 2) works from a political economy perspective. Sociopsychological approaches focus on how "group-related attitudes and symbols" shape attitudes toward immigrants (Hainmueller \& Hopkins, 2014, p. 226). This perspective relies on features, including race, religion and language, to explain native-immigrant differences. Natives perceive between-group differences as threats to their national identity, which justifies their demands for assimilation and language attainment, their tendencies to stereotype and to be prejudiced (Hainmueller \& Hopkins, 2014). In contrast, the political economy view understands attitudes toward immigrants in terms of native-born citizens' material self- interest, highlighting distributional consequences due to resource competition between immigrants and natives, and due to an increased tax burden as a result of immigration (Hainmueller \& Hopkins, 2014).

\section{Explaining Chief Executives' Approval of Immigrants}

\section{Psychological Approach: The Role of Empathy} People's attitudinal variation toward immigrants from different ethnic backgrounds (e.g., Latinos, Asians, etc.) has been explained by emotions. In this research, observational and empirical studies have focused on the role of a particular emotion - anxiety (Brader et al., 2008; Gadarian \& Alberston, 2014). For instance, in an experimental study Brader et al. (2008) manipulate the image/tone of a newspaper article and the featured immigrant group (European or Latino) to test people's anxiety concerning immigration. Likewise, Alberston and Gadarian (2013) experimentally manipulate advertisement content to demonstrate that a threatening ad leads to more negative attitudes toward immigrants among non-Hispanic, white Republicans.

Nevertheless, very few empirical studies assess the role of empathy on attitudes toward immigrants. To a certain extent, studies addressing the role of policy framing on immigration attitudes relate to emotions. For instance, Merolla et al. (2013) highlight the divergent framing efforts 
over legalization programs and point to the DREAM Act to illustrate proponents' strategy to benefit those who arrived in the U.S. as young children with their parents. The idea is people tend to be more sensitive/empathetic to certain labels/framings. Hence, respondents were asked about the level of agreement over whether "[illegal/ undocumented/ unauthorized] immigrants [who immigrated as young children] should be able to earn legal status if they graduated from a U.S. high school, stayed out of trouble and enrolled in college or the military." (Merolla et al., 2013, p. 796). They reported greater support (54 percent) than opposition to the policy (30 percent), and only 16 percent were neutral. Other studies illustrate voters are sensitive to appeals regarding the effects of policies on children, such as an incarceration policy (Cullen et al., 2000), health programs addressing obesity (Zivkovic et al., 2010), and gay rights (Miceli, 2005).

As with age, people may be more empathetic toward migrants depending on the migration cause. The role of emotions in decision making has received considerable attention (Lopes, 1987; Clore, 1992; Forgas, 1995; Lerner \& Keltner, 2000; Gutnik et al., 2006, Lerner et al., 2015). According to Loewenstein and Lerner (2003), emotions affect decision making in two different ways: immediate emotions and expected emotions. Immediate emotions consist of emotions such as sadness or anger that are experienced in the moment of making a decision. Those emotions are expected to have both a direct and indirect impact on decision making. On the other hand, "expected emotions consist of predictions about the emotional consequence of decision outcomes" (Loewenstein \& Lerner, 2003, p. 620). That is, the decision-maker anticipates emotions generated by a decision's consequences. Given expected emotions generated by decisions, "people are assumed to choose options that they expect will maximize the net balance of positive to negative emotions" (Loewenstein \& Lerner, 2003, p. 621).

Here, we contend chief executives' approval of immigrants is also a function of emotions, specifically of empathy generated by their migration cause. The rationale is that given a specific migration cause, chief executives may anticipate the likelihood of being affected by the same cause, making leaders more empathetic toward immigrants and more prone to receive them. Natural disasters, civil conflicts, pandemics and human rights violations may trigger migration waves. However, each cause may generate varying levels of empathy in leaders of immigrant-recipient countries. For instance, leaders may be more sensitive to receive immigrants due to natural disasters (an external shock), as they may anticipate that they could be affected by the same cause as well. Conversely, immigration waves due to civil conflicts or epidemics seem to be perceived more within government control, which may diminish leaders' empathy. Bansak et al. (2016), for example, show how Europeans change their attitudes toward asylum seekers depending on refugees' cause of migration. Therefore, this study suggests chief executives' approval of immigrants is a function of the cause of migration.

\section{H1: Chief executives are more likely to accept an influx} of immigrants when the cause of immigration is known.

H2: Chief executives are more likely to accept an influx of immigrants due to a natural disaster instead of a domestic civil conflict.

Nevertheless, the influence of empathy on chief executives' approval of immigrants may be moderated by the size of immigration influx. The notion is that chief executives' anticipated impact of immigration size on their jurisdictions' racial composition, service provision, and assimilation strategies may moderate their attitude toward immigrants.

H3: As the size of the immigration influx increases, the positive effect of empathy on chief executives' approval for immigrants decreases.

\section{Survey-Experiment Design}

To test our propositions, we use data from a survey-experiment using 101 Latin American mayors. The experiment was conducted in Spanish during the Hemispheric Summit of Mayors, sponsored by the National Federation of Mexican Municipalities (FENAMM in Spanish) and the Latin American Federation of Cities, Municipalities and Associations of Local Governments (FLACMA in Spanish). The summit occurred Aug. 23-26, 2017, in Pachuca, Hidalgo. We received permission to 
attend the conference from FENAMM and attended all events. Participation in the survey-experiment was voluntary, and mayors remained anonymous unless they provided their names. We obtained Institutional Review Board approval for the study from our home institution. The authors explained the investigation's purposes and asked for mayors' participation. After agreeing to cooperate, each mayor was presented with a hypothetical municipal scenario and asked to state whether they would agree to accept the immigrants. Then, mayors were given a 24-question survey about their education, public sector experience, political aspirations and affiliation, attitudes towards migration and cultural views. Our main goal was to approach as many mayors as possible.

The authors and two assistants approached mayors after meals, during breaks and in the lobby and exhibition hall. Each mayor was assigned to one of five municipal scenarios by chance. To guarantee random assignment, we organized the municipal conditions in stacks including the five scenarios, arranged from 1 to 5 . Every time we approached a mayor, we selected the scenario at the top. As a result, about 20 mayors were placed in each scenario for a total of $101(101 / 5=$ 20).

\section{Introducing the Issue: Accepting Migrants}

As mentioned above, mayors were randomly allocated to one of five versions of the vignette (see Figure 1). Each vignette asks mayors to assume they are mayors of a border municipality with a population of 150,000 . We then asked mayors to assume their national governments requested them to accept 1,500 immigrants from a neighboring country. Finally, mayors were asked to either accept or reject the immigrants.

\section{Introducing the Treatments: Migration Cause and Size}

The study involves one control (no cause mentioned and 1,500 immigrants) and four experimental conditions [cause 1 (1,500 vs. 3,000 immigrants), and cause 2 (1,500 vs. 3,000 immigrants)]. The control group is used as baseline for the cause conditions that also include 1,500 immigrants, but not for the ones with 3,000 immigrants. Therefore, it is not a "real" control, in the conventional sense. ${ }^{1}$ In other words, the control group allows us to test whether mentioning the migration cause affects mayoral approval of immigrants relative to the control condition (H1). The control group informed mayors that the neighboring country was small, politically and economically stable and that the migration wave size was 1,500 . In the first treatment, the number of immigrants remained the same $(1,500)$, but we manipulated the cause. Mayors were told the migration cause was due to a natural disaster, specifically an earthquake. In the second treatment, the number of immigrants remained the same as with the control group $(1,500)$, but we manipulated the migration cause. In this case, it was due to a civil conflict. As in treatments 1 and 2, the influx size remains the same as in the control group. Any change in mayoral approval should be due to mentioning immigration cause. To test whether mayoral approval depends on the specific immigration cause (H2), we compare mayoral approval in treatment 1 (natural disaster) to mayoral approval in treatment 2 (civil conflict).

As we are interested in testing whether size of immigration influx moderates the effect of migration cause on mayors' approval of immigrants (H3), we manipulated the cause and size of migration in treatments 3 and 4 . In treatment 3 , the immigrant number was 3,000 and the cause was a natural disaster. In treatment 4 , the immigrant number was 3,000 and the cause was a civil conflict.

\section{Manipulation Checks}

As a manipulation check, in the post-treatment survey mayors were asked, generally, if they would be willing to accept immigrants. From the 77 mayors who accepted immigrants in the experiment, 69 again were willing to accept immigrants in the survey question. That meant 89 percent of survey answers are aligned with experiment answers. Wealso asked mayors which reason makes them more likely to accept immigrants: a natural disaster or a civil/political conflict. Sixty-five percent selected natural disaster.

\section{Data and Variable Operationalization}

Mayors participating in the survey-experiment belong to 18 Latin American and Caribbean countries: North America (Mexico), Central America (Belize, Costa Rica, Guatemala, Honduras, and Panama), Caribbean (Dominica, Jamaica, Puerto Rico, and Dominican Republic), and South America (Argentina, Bolivia, Brazil, Chile, Colombia, Ecuador, Paraguay and Peru). Of the 101 mayors, 37.6 percent were from Mexico, 31.6 percent from South America, 19.8 percent from Central America, and 10.8 percent from the Caribbean (See Figure 2). Given the conference took place in Mexico, Mexican 


\section{Figure 1 \\ Experimental vignette}

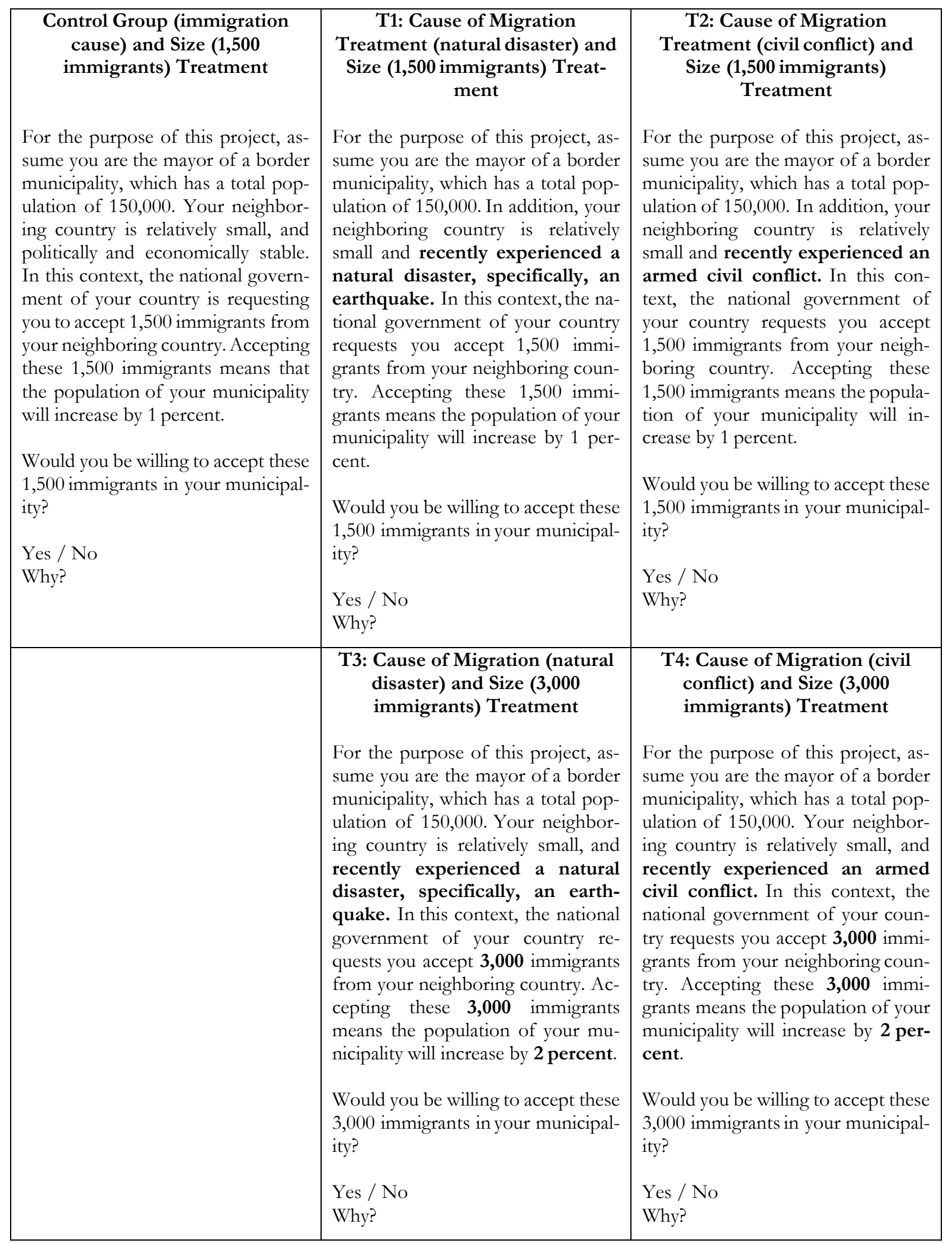


Figure 2

Number of mayors by country

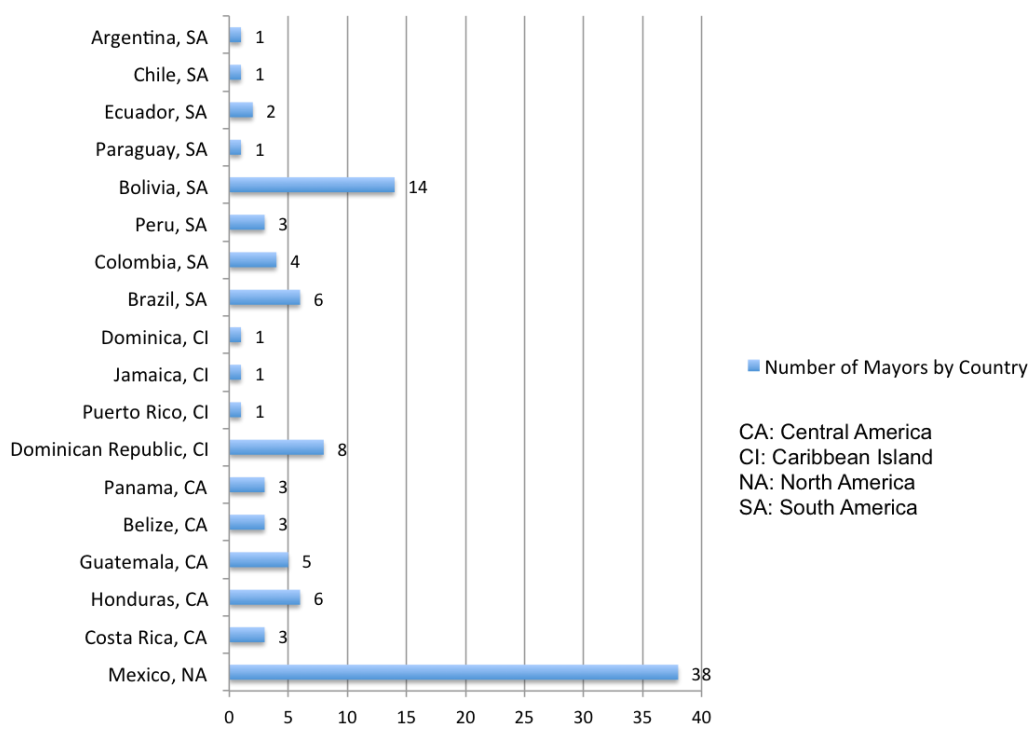

Table 1

Number of mayors per region and treatment condition

\begin{tabular}{lccccc}
\hline \hline & & \multicolumn{4}{c}{ Treatment Conditions } \\
\cline { 3 - 6 } $\begin{array}{c}\text { Number of Mayors } \\
\text { per Region }\end{array}$ & Control Group & Natural Disaster & Civil Conflict & $\begin{array}{c}\text { Natural Disaster } \\
\text { \& Immigration } \\
\text { Influx }\end{array}$ & $\begin{array}{c}\text { Civil Conflict \& } \\
\text { Immigration } \\
\text { Influx }\end{array}$ \\
\hline North America & 9 & 6 & 7 & 10 & 6 \\
Central America & 4 & 5 & 3 & 3 & 5 \\
Caribbean Islands & 3 & 2 & 2 & 2 & 2 \\
South America & 4 & 7 & 13 & 19 & 4 \\
Total of Subjects & 20 & 20 & 25 & $100 \%$ & $65 \%$ \\
Mayors Approving & $50 \%$ & $80 \%$ & $92 \%$ & & 17 \\
Immigrants & & & & & 5 \\
\hline
\end{tabular}

mayors were overrepresented. However, due to the random assignment, Mexican mayors were not systematically overrepresented in any treatment group (see Table 1). Based on populations reported by mayors, our sample closely reflects the proportion of city-size categories in the region (Rodriguez, 2007), from which we are confident in the external validity of the study.

Our outcome variable, mayoral willingness to accept immigrants, is operationalized as a dummy variable that equals " 1 " if the mayor responded "yes" to the experiment's question: "Would you be willing to accept these immigrants in your municipality?" and " 0 " otherwise. We created a dummy variable for the control group and a dummy variable for each treatment group to test the effect of mentioning the migration cause (H1), to compare the effect of two different migration causes (H2), and to estimate the moderating effect of migration size (H3) on mayors' approval of immigrants. Through the survey and administrative data, we gathered information for control variables. These factors include mayors' characteristics - such as age, gender, ideology and educational attainment and municipalities' characteristics - such as total and rural population, distance to neighboring country, unemployment rates at the state, department or province to which the municipality belongs to, and region in the continent. 
Table 2

Means of treatment conditions across variables of interest

\begin{tabular}{|c|c|c|c|c|c|}
\hline Variables & $\begin{array}{l}\text { Control } \\
\text { Group }\end{array}$ & $\begin{array}{l}\text { T1: Natural } \\
\text { Disaster }\end{array}$ & $\begin{array}{l}\text { T2: Civil } \\
\text { Conflict }\end{array}$ & $\begin{array}{c}\text { T3: Natural } \\
\text { Disaster \& Size }\end{array}$ & $\begin{array}{c}\text { T4: Civil } \\
\text { Conflict \& Size }\end{array}$ \\
\hline \multicolumn{6}{|l|}{ Mayor's Characteristics } \\
\hline Female & $\begin{array}{c}0.10 \\
(0.31)\end{array}$ & $\begin{array}{c}0.10 \\
(0.31)\end{array}$ & $\begin{array}{c}0.16 \\
(0.37)\end{array}$ & $\begin{array}{c}0.00 \\
(0.00)\end{array}$ & $\begin{array}{c}0.24 \\
(0.44)\end{array}$ \\
\hline Age & $\begin{array}{l}53.75 \\
(9.51)\end{array}$ & $\begin{array}{l}47.50 \\
(9.57)\end{array}$ & $\begin{array}{l}48.17 \\
(8.66)\end{array}$ & $\begin{array}{l}48.24 \\
(6.95)\end{array}$ & $\begin{array}{l}47.06 \\
(8.47)\end{array}$ \\
\hline Less Than High School & $\begin{array}{c}0.15 \\
(0.37)\end{array}$ & $\begin{array}{c}0.20 \\
(0.41)\end{array}$ & $\begin{array}{c}0.20 \\
(0.41)\end{array}$ & $\begin{array}{c}0.21 \\
(0.42)\end{array}$ & $\begin{array}{c}0.29 \\
(0.47)\end{array}$ \\
\hline College Degree & $\begin{array}{c}0.65 \\
(0.49)\end{array}$ & $\begin{array}{c}0.55 \\
(0.51)\end{array}$ & $\begin{array}{c}0.48 \\
(0.51)\end{array}$ & $\begin{array}{c}0.58 \\
(0.51)\end{array}$ & $\begin{array}{c}0.53 \\
(0.51)\end{array}$ \\
\hline Graduate Degree & $\begin{array}{c}0.20 \\
(0.41)\end{array}$ & $\begin{array}{c}0.25 \\
(0.44)\end{array}$ & $\begin{array}{c}0.32 \\
(0.48)\end{array}$ & $\begin{array}{l}0.21 \\
(0.42)\end{array}$ & $\begin{array}{c}0.18 \\
(0.39)\end{array}$ \\
\hline Conservative Ideology & $\begin{array}{c}0.05 \\
(0.22)\end{array}$ & $\begin{array}{c}0.20 \\
(0.41)\end{array}$ & $\begin{array}{c}0.24 \\
(0.44)\end{array}$ & $\begin{array}{c}0.21 \\
(0.42)\end{array}$ & $\begin{array}{c}0.35 \\
(0.49)\end{array}$ \\
\hline \multicolumn{6}{|l|}{ Municipal Characteristics } \\
\hline Rural Population $(\%)$ & $\begin{array}{c}0.41 \\
(0.27)\end{array}$ & $\begin{array}{c}0.47 \\
(0.30)\end{array}$ & $\begin{array}{c}0.61 \\
(0.31)\end{array}$ & $\begin{array}{c}0.50 \\
(0.34)\end{array}$ & $\begin{array}{c}0.40 \\
(0.31)\end{array}$ \\
\hline Municipal Population & $\begin{array}{c}123647.50 \\
(266318.10)\end{array}$ & $\begin{array}{l}52399.00 \\
(71213.37)\end{array}$ & $\begin{array}{c}124393.30 \\
(255275.50)\end{array}$ & $\begin{array}{c}102403.20 \\
(182235.20)\end{array}$ & $\begin{array}{c}111973.60 \\
(194946.30)\end{array}$ \\
\hline $\begin{array}{l}\text { Distance to Neighboring } \\
\text { Country }(\mathrm{Km})\end{array}$ & $\begin{array}{c}489.59 \\
(449.20)\end{array}$ & $\begin{array}{c}417.88 \\
(432.17)\end{array}$ & $\begin{array}{c}420.53 \\
(446.69)\end{array}$ & $\begin{array}{c}425.54 \\
(307.15)\end{array}$ & $\begin{array}{l}296.27 \\
(260.62)\end{array}$ \\
\hline \multicolumn{6}{|c|}{ State, Department or Province Characteristics } \\
\hline Unemployment Rate & $\begin{array}{c}6.86 \\
(5.58)\end{array}$ & $\begin{array}{c}5.92 \\
(4.42)\end{array}$ & $\begin{array}{c}4.86 \\
(4.34)\end{array}$ & $\begin{array}{c}3.38 \\
(1.50)\end{array}$ & $\begin{array}{l}4.74 \\
(2.96)\end{array}$ \\
\hline \multicolumn{6}{|l|}{ Country Characteristics } \\
\hline Caribbean Country & $\begin{array}{c}0.15 \\
(0.37)\end{array}$ & $\begin{array}{c}0.10 \\
(0.31)\end{array}$ & $\begin{array}{c}0.08 \\
(0.28)\end{array}$ & $\begin{array}{c}0.11 \\
(0.32)\end{array}$ & $\begin{array}{c}0.12 \\
(0.33)\end{array}$ \\
\hline Central American Country & $\begin{array}{c}0.20 \\
(0.41)\end{array}$ & $\begin{array}{c}0.25 \\
(0.44)\end{array}$ & $\begin{array}{c}0.12 \\
(0.33)\end{array}$ & $\begin{array}{c}0.16 \\
(0.37)\end{array}$ & $\begin{array}{c}0.29 \\
(0.47)\end{array}$ \\
\hline North American: Mexico & $\begin{array}{c}0.45 \\
(0.51)\end{array}$ & $\begin{array}{c}0.30 \\
(0.47)\end{array}$ & $\begin{array}{c}0.28 \\
(0.46)\end{array}$ & $\begin{array}{c}0.53 \\
(0.51)\end{array}$ & $\begin{array}{c}0.35 \\
(0.49)\end{array}$ \\
\hline South American Country & $\begin{array}{c}0.20 \\
(0.41)\end{array}$ & $\begin{array}{c}0.35 \\
(0.49)\end{array}$ & $\begin{array}{c}0.52 \\
(0.51)\end{array}$ & $\begin{array}{c}0.21 \\
(0.42)\end{array}$ & $\begin{array}{c}0.24 \\
(0.44)\end{array}$ \\
\hline Mestizo Population (\%) & $\begin{array}{c}59.10 \\
(20.50) \\
\end{array}$ & $\begin{array}{c}60.54 \\
(24.16) \\
\end{array}$ & $\begin{array}{c}62.97 \\
(15.74) \\
\end{array}$ & $\begin{array}{l}60.28 \\
(8.04) \\
\end{array}$ & $\begin{array}{c}63.28 \\
(12.28) \\
\end{array}$ \\
\hline
\end{tabular}

Note: Standard deviation in parentheses

Tables 2 and 3 present control variables' means for each experimental condition and differences in means between them, respectively. Generally, mayors' characteristics are not statistically different across the five groups; meaning composition of subjects is balanced. The few variables for which we see statistical difference between the control and a treatment group do not systematically belong to a specific group. Therefore, the randomization process was effective.

\section{Analysis and Results}

In general, results indicate Latin American and Caribbean mayors tend to be empathetic toward immigrants, as 79 percent approved receiving immigrants regardless of cause and size of migration. According to Table 1, 50 percent of mayors approved immigrants in the control group; 80 percent approved when the cause of immigration is a 
Table 3

\section{Differences in means across treatment conditions}

\begin{tabular}{|c|c|c|c|c|c|}
\hline Variables & $\begin{array}{c}\text { Natural } \\
\text { Disaster (T1) } \\
\text { vs. Control }\end{array}$ & $\begin{array}{c}\text { Civil Conflict } \\
\text { (T2) vs. } \\
\text { Control }\end{array}$ & $\begin{array}{c}\text { Natural } \\
\text { Disaster (T1) } \\
\text { vs. Civil } \\
\text { Conflict (T2) }\end{array}$ & $\begin{array}{c}\text { Natural } \\
\text { Disaster (T1) } \\
\text { vs. Natural } \\
\text { Disaster \& } \\
\text { Size (T3) }\end{array}$ & $\begin{array}{l}\text { Civil Conflict } \\
\text { (T2) vs. Civil } \\
\text { Conflict \& } \\
\text { Size (T4) }\end{array}$ \\
\hline \multicolumn{6}{|l|}{ Mayor's Characteristics } \\
\hline \multirow[t]{2}{*}{ Female } & 0.0 & 0.06 & 0.060 & -0.100 & 0.075 \\
\hline & $(0.097)$ & $(0.102)$ & $(0.102)$ & $(0.069)$ & $(0.130)$ \\
\hline \multirow[t]{2}{*}{ Age } & 6.25 & 5.576 & -0.674 & -0.735 & 1.115 \\
\hline & $(3.098)$ & $(2.772)$ & $(2.854)$ & $(2.842)$ & $(2.745)$ \\
\hline \multirow[t]{2}{*}{ Less Than High School } & 0.05 & 0.05 & 0.000 & 0.011 & 0.094 \\
\hline & $(0.123)$ & $(0.116)$ & $(0.123)$ & $(0.133)$ & $(0.140)$ \\
\hline \multirow[t]{2}{*}{ College Degree } & -0.1 & -0.17 & -0.070 & 0.029 & 0.049 \\
\hline & $(0.158)$ & $(0.15)$ & $(0.153)$ & $(0.163)$ & $(0.161))$ \\
\hline \multirow[t]{2}{*}{ Graduate Degree } & 0.05 & 0.12 & 0.070 & -0.039 & -0.144 \\
\hline & $(0.135)$ & $(0.133)$ & $(0.138)$ & $(0.138)$ & $(0.135)$ \\
\hline \multirow[t]{2}{*}{ Conservative Ideology } & 0.15 & 0.19 & 0.040 & 0.011 & 0.113 \\
\hline & $(0.104)$ & $(0.101)$ & $(0.127)$ & $(0.133)$ & $(0.148)$ \\
\hline \multicolumn{6}{|l|}{ Municipal Characteristics } \\
\hline \multirow[t]{2}{*}{ Rural Population (\%) } & -0.061 & $-0.193 *$ & -0.131 & -0.027 & $0.208^{*}$ \\
\hline & $(0.089)$ & $(0.088)$ & -0.131 & $(0.101)$ & $(0.098)$ \\
\hline \multirow[t]{2}{*}{ Municipal Population } & 71000 & -745.82 & -72000 & -50000 & 12000 \\
\hline & $(62000)$ & $(78000)$ & $(59000)$ & $(44000)$ & $(73000)$ \\
\hline Distance to Neighboring & 71.713 & 69.054 & -2.659 & -7.665 & 124.261 \\
\hline Country $(\mathrm{Km})$ & $(139.383)$ & $(134.34)$ & $(132.099)$ & $(120.639)$ & $(120.484)$ \\
\hline \multicolumn{6}{|c|}{ State, Department or Province Characteristics } \\
\hline \multirow[t]{2}{*}{ Unemployment Rate } & 0.94 & 1.996 & 1.056 & $2.541 *$ & 0.129 \\
\hline & $(1.592)$ & $(1.477)$ & $(1.313)$ & $(1.069)$ & $(1.210)$ \\
\hline \multicolumn{6}{|l|}{ Country Characteristics } \\
\hline \multirow[t]{2}{*}{ Caribbean Country } & -0.05 & -0.07 & -0.020 & 0.005 & 0.038 \\
\hline & $(0.107)$ & $(0.099)$ & $(0.088)$ & $(0.100)$ & $(0.098)$ \\
\hline \multirow[t]{2}{*}{ Central American Country } & 0.05 & -0.08 & -0.130 & -0.092 & 0.174 \\
\hline & $(0.135)$ & $(0.113)$ & $(0.120)$ & $(0.131)$ & $(0.132)$ \\
\hline \multirow[t]{2}{*}{ North American: Mexico } & -0.15 & -0.17 & -0.020 & 0.226 & 0.073 \\
\hline & $(0.155)$ & $(0.147)$ & $(0.140)$ & $(0.158)$ & $(0.150)$ \\
\hline \multirow[t]{2}{*}{ South American Country } & 0.15 & $0.320^{*}$ & 0.170 & -0.139 & -0.285 \\
\hline & $(0.143)$ & $(0.138)$ & $(0.150)$ & $(0.146)$ & $(0.147)$ \\
\hline \multirow[t]{2}{*}{ Mestizo Population ( $\%)$} & -1.447 & -3.871 & -2.424 & 0.265 & -0.314 \\
\hline & $(7.085)$ & $(5.4)$ & $(5.971)$ & $(5.830)$ & $(4.544)$ \\
\hline
\end{tabular}

Note: Standard errors in parentheses. ${ }^{*} p<0.10,{ }^{* *} p<0.05,{ }^{* * *} p<0.001$

natural disaster; 92 percent approved when the cause is civil conflict; 100 percent approved when the cause is a natural disaster and the number of immigrants increases; and 66 percent approved when the cause is civil conflict and the size of migration wave increases.

Table 4 presents the OLS estimates for mayoral approval of immigrants, which we use to test our three hypotheses (see M1 for H1; M2 for $\mathrm{H} 2$; and M3 and M4 for H3). The models in this table only control for region fixed effects. As a robustness check, we also computed OLS estimations controlling for mayors' age, gender, ideology and educational attainment, municipalities' total and rural population, distance to neighboring 
Table 4

OLS estimates for mayoral approval of immigrants

\begin{tabular}{|c|c|c|c|c|}
\hline & $\begin{array}{c}\text { (M1) } \\
\text { Mayoral } \\
\text { Approval of } \\
\text { Immigrants }\end{array}$ & $\begin{array}{c}\text { (M2) } \\
\text { Mayoral } \\
\text { Approval of } \\
\text { Immigrants } \\
\end{array}$ & $\begin{array}{c}\text { (M3) } \\
\text { Mayoral } \\
\text { Approval of } \\
\text { Immigrants }\end{array}$ & $\begin{array}{c}\text { (M4) } \\
\text { Mayoral } \\
\text { Approval of } \\
\text { Immigrants }\end{array}$ \\
\hline $\begin{array}{l}\text { H1: Natural Disaster (T1) vs. Control Group as } \\
\text { base category }\end{array}$ & $0.250^{*}$ & & & \\
\hline H1: Civil Conflict (T2) vs. Control Group as & $0.346^{* *}$ & & & \\
\hline $\begin{array}{l}\text { base category } \\
\text { H2: Natural Disaster (T1) vs. Civil Conflict (T2) } \\
\text { as base category }\end{array}$ & $(0.117)$ & $\begin{array}{c}0.085 \\
(0.096)\end{array}$ & & \\
\hline $\begin{array}{l}\text { H3: Natural Disaster (T1) \& Immigration Influx } \\
\text { vs. Natural Disaster (T3) as base category }\end{array}$ & & & $\begin{array}{l}0.218^{* *} \\
(0.103)\end{array}$ & \\
\hline $\begin{array}{l}\text { H3: Civil Conflict (T2) \& Immigration Influx vs. } \\
\text { Civil Conflict (T4) as base category }\end{array}$ & & & & $\begin{array}{l}-0.241^{*} \\
(0.136)\end{array}$ \\
\hline Region Fixed Effects & Yes & Yes & Yes & Yes \\
\hline Constant & $\begin{array}{l}0.276^{* *} \\
(0.107)\end{array}$ & $\begin{array}{c}0.647^{* * *} \\
(0.147)\end{array}$ & $\begin{array}{c}0.739^{* * *} \\
(0.136)\end{array}$ & $\begin{array}{c}0.727^{* * *} \\
(0.149)\end{array}$ \\
\hline $\mathrm{N}$ & 65 & 45 & 39 & 42 \\
\hline
\end{tabular}

country, unemployment rates at the state, department or province to which the municipality belongs, and regional fixed effects. (See Table 5 M1 and M2 for H1; Table 5 M1 for H2; and Table 6 $\mathrm{M} 2$ and M3 for H3). Results from the more comprehensive models are similar. ${ }^{2}$ Thus, we report results from the simplified version of the OLS estimation (Table 4).

To test Hypothesis 1, whether specifying the migration cause affects mayoral approval, we compare in M1 of Table 4 mayors' approval of immigrants due to natural disaster against mayors' approval for immigrants when no immigration cause is given, which is the control group and the base category. Likewise, we compare mayors' approval of immigrants due to civil conflict against mayors' approval for immigrants when no immigration cause is given, the base category. The number of observations is 65 .

According to Table 4 (M1), the coefficient on natural disaster/T1 is positive and statistically different from the control group (the base category) at the 90 percent confidence level. This means the proportion of mayoral approval in treatment 1 is statistically different from the same proportion in the control (the base category). Likewise, the coefficient on civil conflict/T2 is positive and statistically different from the control group (the base category) at the 95 percent confidence level. That is, the proportion of mayoral approval in treatment 2 is statistically different from the same proportion in the control group. Consequently, $\mathrm{H} 1$ receives empirical support through both tests.

To test whether mayors are more likely to accept an influx of immigrants due to a natural disaster instead of a domestic civil conflict (H2), M2 in Table 4 compares mayoral approval of immigrants due to civil conflict against mayoral approval of immigrants due to natural disaster (the base category). The number of observations is 45 . According to Table 4 (M2), the proportion of mayoral approval due to natural disaster is not statistically different from the proportion of mayoral approval due to civil conflict. Therefore, $\mathrm{H} 2$ fails to receive empirical support. This result suggests Latin American mayors are equally empathetic toward these two immigration causes. However, we caution about interpreting this as a null effect since the power of our estimation is rather small (0.12). Moreover, the power test suggests our coefficient might reach statistical significance with a sample size of 505 observations.

To test whether the size of immigration 
Table 5

OLS estimates for mayoral approval of immigrants (H1)

\begin{tabular}{|c|c|c|}
\hline & $\begin{array}{c}\text { (M1) } \\
\text { Mayoral Approval of } \\
\text { Immigrants }\end{array}$ & $\begin{array}{c}\text { (M2) } \\
\text { Mayoral Approval of } \\
\text { Immigrants }\end{array}$ \\
\hline H1: Natural Disaster ${ }^{+}$ & $\begin{array}{c}0.337^{* *} \\
(0.135)\end{array}$ & $\begin{array}{l}0.270^{*} \\
(0.147)\end{array}$ \\
\hline H1: Civil Conflict ${ }^{+}$ & $\begin{array}{c}0.396^{* *} \\
(0.120)\end{array}$ & $\begin{array}{l}0.388^{* *} \\
(0.131)\end{array}$ \\
\hline Natural Disaster \& Immigration Influx ${ }^{+}$ & $\begin{array}{c}0.541^{* * *} \\
(0.113)\end{array}$ & \\
\hline Civil Conflict \& Immigration Influx ${ }^{+}$ & $\begin{array}{c}0.138 \\
(0.160)\end{array}$ & \\
\hline Control Variables & & \\
\hline Mayor's College Degree ${ }^{++}$ & $\begin{array}{c}0.020 \\
(0.107)\end{array}$ & $\begin{array}{c}0.031 \\
(0.152)\end{array}$ \\
\hline Mayor's Graduate Degree $^{++}$ & $\begin{array}{l}-0.025 \\
(0.114)\end{array}$ & $\begin{array}{l}-0.013 \\
(0.155)\end{array}$ \\
\hline Female Mayor & $\begin{array}{c}0.065 \\
(0.105)\end{array}$ & $\begin{array}{l}-0.035 \\
(0.108)\end{array}$ \\
\hline Mayor's Conservative Ideology & $\begin{array}{l}-0.021 \\
(0.114)\end{array}$ & $\begin{array}{c}0.041 \\
(0.151)\end{array}$ \\
\hline Unemployment Rate (subnational level) & $\begin{array}{l}-0.008 \\
(0.014)\end{array}$ & $\begin{array}{l}-0.010 \\
(0.015)\end{array}$ \\
\hline Municipal Rural Population (\%) & $\begin{array}{l}-0.083 \\
(0.122)\end{array}$ & $\begin{array}{l}-0.316^{*} \\
(0.163)\end{array}$ \\
\hline Municipal Population in Thousands & $\begin{array}{c}0.000 \\
(0.000)\end{array}$ & $\begin{array}{c}0.000 \\
(0.000)\end{array}$ \\
\hline $\begin{array}{l}\text { Municipal Distance to Neighboring } \\
\text { Country }(\mathrm{Km})\end{array}$ & $\begin{array}{c}0.000 \\
(0.000)\end{array}$ & $\begin{array}{c}0.008 \\
(0.014)\end{array}$ \\
\hline Caribbean Country ${ }^{+++}$ & $\begin{array}{c}0.529^{* *} \\
(0.162)\end{array}$ & $\begin{array}{l}0.601^{* *} \\
(0.223)\end{array}$ \\
\hline Central American Country ${ }^{+++}$ & $\begin{array}{l}0.328^{*} \\
(0.174)\end{array}$ & $\begin{array}{c}0.274 \\
(0.236)\end{array}$ \\
\hline South American Country ${ }^{+++}$ & $\begin{array}{c}0.339^{* *} \\
(0.105)\end{array}$ & $\begin{array}{l}0.448^{* *} \\
(0.139)\end{array}$ \\
\hline Constant & $\begin{array}{c}0.253 \\
(0.192)\end{array}$ & $\begin{array}{l}0.395^{*} \\
(0.214)\end{array}$ \\
\hline $\mathrm{N}$ & 101 & 65 \\
\hline
\end{tabular}

Note: Standard errors in parentheses, ${ }^{*} p<0.10,{ }^{* *} p<0.05,{ }^{* * *} p<0.001,+$ The excluded category is the control group, ++ The excluded category is High School Degree, +++ The excluded category is Mexico

moderates the effect of immigration cause on mayoral approval (H3), Table 4 (M3) compares mayoral approval of immigrants when the size of immigration presented is 1,500 and the cause is natural disaster against mayoral approval of immigrants when the size of immigration is 3,000 and the cause is natural disaster. According to Table 4 (M3), the coefficient on natural disaster and 3,000 immigrant treatment is positive and statistically significant at the 95 percent confidence level. That is, the proportion of mayoral approval due to natural disaster with an immigration size of 3,000 is higher and statistically different from the proportion of mayoral approval of immigrants due to natural disaster and an immigration size of 1,500. This means that as the presented number of immigrants increases, mayoral approval of immigrants due to a natural disaster also increases. 
Table 6

OLS estimates for mayoral approval of immigrants (H2 \& $\mathbf{H} 3)$

\begin{tabular}{|c|c|c|c|}
\hline & $\begin{array}{c}\text { (M1) } \\
\text { Mayoral Approval of } \\
\text { Immigrants } \\
\end{array}$ & $\begin{array}{c}\text { (M2) } \\
\text { Mayoral Approval of } \\
\text { Immigrants } \\
\end{array}$ & $\begin{array}{c}\text { (M3) } \\
\text { Mayoral Approval of } \\
\text { Immigrants } \\
\end{array}$ \\
\hline H2: Civil Conflict vs. Natural & 0.069 & & \\
\hline Disaster (Base category) & $(0.108)$ & & \\
\hline H3: Natural Disaster \& & & $0.283^{*}$ & \\
\hline Immigration Influx vs. Natural & & $(0.142)$ & \\
\hline Disaster (Base category) & & & \\
\hline H3: Civil Conflict \& Immigration & & & $-0.266^{* *}$ \\
\hline $\begin{array}{l}\text { Influx vs. Civil Conflict (Base } \\
\text { category) }\end{array}$ & & & $(0.123)$ \\
\hline \multicolumn{4}{|l|}{ Control Variables } \\
\hline \multirow[t]{2}{*}{ Mayor's College Degree ${ }^{+}$} & 0.038 & 0.004 & -0.044 \\
\hline & $(0.134)$ & $(0.184)$ & $(0.174)$ \\
\hline \multirow[t]{2}{*}{ Mayor's Graduate Degree ${ }^{+}$} & -0.010 & 0.034 & -0.112 \\
\hline & $(0.140)$ & $(0.193)$ & $(0.158)$ \\
\hline \multirow[t]{2}{*}{ Female Mayor } & 0.059 & 0.228 & 0.186 \\
\hline & $(0.124)$ & $(0.186)$ & $(0.171)$ \\
\hline \multirow{2}{*}{ Mayor's Conservative Ideology } & $0.257^{*}$ & 0.195 & 0.160 \\
\hline & $(0.151)$ & $(0.151)$ & $(0.182)$ \\
\hline \multirow{2}{*}{$\begin{array}{l}\text { Unemployment Rate (subnational } \\
\text { level) }\end{array}$} & -0.014 & 0.001 & $-0.048^{*}$ \\
\hline & $(0.022)$ & $(0.021)$ & $(0.028)$ \\
\hline \multirow[t]{2}{*}{ Municipal Rural Population (\%) } & -0.286 & -0.063 & -0.080 \\
\hline & $(0.238)$ & $(0.159)$ & $(0.245)$ \\
\hline \multirow[t]{2}{*}{ Municipal Population in Thousands } & 0.000 & $-0.001^{*}$ & 0.000 \\
\hline & $(0.000)$ & $(0.000)$ & $(0.000)$ \\
\hline Municipal Distance to Neighboring & 0.006 & 0.008 & 0.042 \\
\hline Country $(\mathrm{Km})$ & $(0.017)$ & $(0.020)$ & $(0.026)$ \\
\hline \multirow[t]{2}{*}{ Caribbean Country $^{++}$} & 0.362 & 0.176 & $0.812^{* *}$ \\
\hline & $(0.249)$ & $(0.169)$ & $(0.262)$ \\
\hline \multirow[t]{2}{*}{ Central American Country ${ }^{++}$} & -0.036 & -0.058 & 0.443 \\
\hline & $(0.251)$ & $(0.184)$ & $(0.301)$ \\
\hline \multirow[t]{2}{*}{ South American Country ${ }^{++}$} & $0.347^{*}$ & 0.223 & $0.449^{* *}$ \\
\hline & $(0.186)$ & $(0.157)$ & $(0.192)$ \\
\hline \multirow[t]{2}{*}{ Constant } & $0.762^{* * *}$ & $0.675^{* *}$ & $0.625^{* *}$ \\
\hline & $(0.175)$ & $(0.310)$ & $(0.265)$ \\
\hline $\mathrm{N}$ & 45 & 39 & 42 \\
\hline
\end{tabular}

Note: Standard errors in parentheses, ${ }^{*} p<0.10,{ }^{* *} p<0.05,{ }^{* * *} p<0.001,+$ The excluded category is High School Degree, ++ The excluded category is Mexico

Therefore, $\mathrm{H} 3$ receives empirical support but in the opposite direction.

Finally, to test again whether the size of immigration moderates the effect of immigration cause on mayoral approval (H3), Table 4 (M4) compares mayoral approval of immigrants when the number of immigrants presented is 1,500 and the cause is civil conflict against mayoral approval of immigrants when the presented number is 3,000 and the cause is civil conflict. According to
Table 4 (M4), the coefficient on natural disaster and 3,000 immigrant treatment is negative and statistically significant at the 95 percent confidence level. That is, the proportion of mayoral approval of 3,000 immigrants due to civil conflict is lower and statistically different from the proportion of mayoral approval of 1,500 immigrants due to civil conflict. This means that as the number of immigrants increases, mayoral approval of immigrants 
due to a civil conflict decreases. Therefore, H3 receives again empirical support.

Based on Table 5 (M1) and Table 6 (M3), results suggest that South American, Caribbean and Central American mayors are more likely to approve immigrants than their Mexican colleagues. We do not have a clear explanation for this result, but we speculate Mexicans' exposure to being a transit country for immigrants heading to the U.S. may make them less sympathetic toward immigrants. Most Central American migrants heading to the U.S. travel across Mexico. Hence, the U.S. government has encouraged Mexico to have a more effective immigration policy and, as a result, the Mexican government has implemented harsher immigration policies toward Central Americans. This might influence Mexican mayors' attitudes toward immigration. However, this interpretation requires further analysis.

\section{Exploratory Qualitative Explanations}

As part of the vignette, we asked mayors to explain reasons for their decisions to accept or reject immigrants. While we did not carry out a formal qualitative analysis, we identified some patterns that support findings from the quantitative analysis. Table 7 presents the types of reasons mayors offered. Mayoral rationales for accepting immigrants include solidarity, love of neighbors, human rights concerns, collaboration, reciprocity and potential for economic development. Mayoral justifications to reject immigrants include: protecting the local population's well-being, lack of resources and administrative capacity, prospects of increasing insecurity, disorder and demands for public services, and current presence of many immigrants. Solidarity and humanitarian reasons were prevalent reasons for justifying acceptance of immigrants. Specifically, about 50 percent of those mayors said they were willing to accept immigrants who fled due to natural disasters or an armed civil conflict. These responses coincide with our expectations that external shocks experienced by certain populations raise empathy toward immigrants.

\section{Limitations and Conclusions}

Our study has limitations. The hypothetical scenarios presented to mayors fail to specify the type
Table 7

\section{Mayoral rationale for approval/} rejection of immigrants

\begin{tabular}{|c|c|}
\hline $\begin{array}{c}\text { Rationale for } \\
\text { Approval }\end{array}$ & $\begin{array}{c}\text { Rationale for } \\
\text { Rejection }\end{array}$ \\
\hline 1. Solidarity & $\begin{array}{l}\text { 1. The well-being and } \\
\text { employment of the } \\
\text { local population } \\
\text { comes first. }\end{array}$ \\
\hline $\begin{array}{l}\text { 2. Humanitarian } \\
\text { reasons (Love of } \\
\text { neighbor and } \\
\text { human rights) }\end{array}$ & $\begin{array}{l}\text { 2. We already have too } \\
\text { many problems. }\end{array}$ \\
\hline $\begin{array}{l}\text { 3. To walk in someone } \\
\text { else's shoes }\end{array}$ & $\begin{array}{l}\text { 3. Only if they come } \\
\text { from a developed } \\
\text { country. }\end{array}$ \\
\hline 4. Reciprocity & $\begin{array}{l}\text { 4. Lack of resources and } \\
\text { administrative } \\
\text { capacity. }\end{array}$ \\
\hline $\begin{array}{l}\text { 5. Migration is } \\
\text { positive for the de- } \\
\text { velopment of cities. }\end{array}$ & $\begin{array}{l}\text { 5. This requires a lot of } \\
\text { planning. }\end{array}$ \\
\hline $\begin{array}{l}\text { 6. We have lived the } \\
\text { same. }\end{array}$ & $\begin{array}{l}\text { 6. Increases insecurity, } \\
\text { disorder and } \\
\text { demands on public } \\
\text { services }\end{array}$ \\
\hline 7. Collaboration & $\begin{array}{l}\text { 7. We already have a lot } \\
\text { of immigrants. }\end{array}$ \\
\hline $\begin{array}{l}\text { 8. Only if it is } \\
\text { temporarily }\end{array}$ & $\begin{array}{l}\text { 8. Only if it is } \\
\text { temporarily }\end{array}$ \\
\hline
\end{tabular}

of skills immigrants possess. This specification can affect chief executives' decision to approve immigrants since the supply of low-skilled labor is expected to lower wages and employment opportunities for natives (Scheve \& Salughter, 2001). In contrast, supply of high-skilled immigrants will increase demand for low-skilled labor (Scheve \& Salughter, 2001). Finally, although statistical tests show subjects are balanced across treatments compared to the control group in terms of regional representation, Mexican mayors are overrepresented in the sample. Also, future studies should address the effect of immigration on other areas, such as policymaking, implementation, governance and ideological polarization. Moreover, future research should address the impact of public opinion on urbanization strategies and politicians' approval of immigrants. Finally, although the study involves a unique sample of actual mayors, sample size is clearly a shortcoming. Hence, as mentioned 
above, the power test of our estimation is rather small.

This study sought to explain whether immigration causes affect chief executives' acceptance decisions. Unlike existing studies explaining immigration attitudes mainly in terms of cultural threats and material self-interest, we suggest chief executives' empathy towards causes of migration influences chief executives' approval of immigrants. We also contend the effect of migration cause is moderated by migration wave size. In general, findings show 79 percent of surveyed mayors approved immigrants regardless of immigration cause. Compared to the control group in which no immigration cause is given, mayors are more likely to approve immigrants fleeing due to disasters and civil conflict, but not at a statistically different rate. When the immigration wave size increases, mayors are more likely to accept immigrants due to natural disasters, rather than civil conflict.

This study contributes to several literatures, including immigration attitudes, decision making and behavioral public administration. Moreover, the study occurred in an understudied setting, Latin America, and included elected decision-makers, contributing to external validity. More experimental studies should make use of actual decision-makers (Avellaneda, 2013). Results show Latin American local chief executives are considerably empathetic toward immigrants, regardless of their cause of migration, even though most countries have faced immigration influxes.

\section{Acknowledgement}

This research was funded by the Indiana University Ostrom Workshop Research Grant. Authors are grateful to Josefina Carcamo and Ricardo Andres Bellow Gomez for their research assistance. Authors also thank FENAMM Directors for providing access to the Hemispheric Summit of Mayors.

\section{Notes}

1. A true control would have omitted cause and size of immigrants. However, as any approval of immigrants very likely depends on their number, we opted for mentioning the size of immigration in the control group.

2. When calculating logit estimates, some characteristics perfectly predict mayors' approval decision (the outcome variable) due to little variation in their responses. This prevents us from reporting logit estimates.

\section{References}

Avellaneda, C. N. (2013), Mayoral Decision Making: Issue Salience, Decision Context and Choice Constraint? An Experimental Study with 120 Latin American Mayors. Journal of Public Administration Research and Theory, 23(3): 631-661.

Albertson, B. and Gadarian S. K. (2013), “Who's afraid of immigration? The effects of pro- and antiimmigrant threatening ads among Latinos, African Americans, and Whites." In Immigration and Public Opinion in Liberal Democracies, pp. 286-304. Taylor and Francis.

Bansak, K., Hainmueller, J. and Hangartner D. (2016), How Economic, Humanitarian, and Religious Concerns Shape European Attitudes toward Asylum-Seekers. Science. doi 10.1126/science.aag2147

Brader, T., Valentino, N. A. and Suhay, E. (2008), What Triggers Public Opposition to Immigration? Anxiety, Group Cues, and Immigration Threat. American Journal of Political Science, 52 (4): 959-78.

Chandler, C. R. and Tsai Y. (2001), Social factors influencing immigration attitudes: an analysis of data from the General Social Survey. The Social Science Journal, 38(2): 177-188.

Card, D., Dustmann, C. and Preston, I. (2012), Immigration, Wages, and Compositional Amenities. Journal of the European Economic Association, 10: 78-119.

Citrin, J., Green, D. P., Muste, C and Wong, C. (1997), Public Opinion toward Immigration Reform: The Role of Economic Motivations. The Journal of Politics, 59 (3): 858-81.

Clore, G. L. (1992), “Cognitive Phenomenology: Feelings and the construction of judgment.” In L. L. Martin and A. Tesser (Eds.), The construction of social judgments pp. 133-163. Hillsdale, NJ: Lawrence Erlbaum Associates.

Cullen, F. T., Fisher, B. S. and Applegate, B. K. (2000), Public Opinion about Punishment and Corrections. Crime and Justice, 27: 1-79.

Esses, V. M., Jackson, L. M. and Armstrong, T. L. (1998), Intergroup Competition and Attitudes toward Immigrants and Immigration: An 
Instrumental Model of Group Conflict. Journal of Social Issues, 54: 699-724.

Forgas J. P. (1995), Mood and judgment: the affect infusion model (AIM). Psychological Bulletin, 117 (1): 39-66.

Gadarian, S. K. and Albertson, B. (2014), Anxiety, Immigration, and the Search for Information. Political Psychology, 35 (2): 133-164.

Gutnik, L. A., Forogh Hakimzada, A., Yoskowitz, N. A. and Patel, V. L. (2006), "The Role of Emotion in Decision-making: a cognitive neuroeconomic approach towards understanding sexual risk behaviour." Journal of Biomedical Informatics, 39(6): 720-736.

Hainmueller, J. and Hopkins, D. J. (2014), "Public Attitudes toward Immigration." Annual Review of Political Science, 17(1): 225-249.

Huddy, L. (2001), From Social to Political Identity: A Critical Examination of Social Identity Theory. Political Psychology, 22: 127-56.

Joppke, C. (1998), Why Liberal States Accept Unwanted Immigration. World Politics, 50(2): 266-293.

Lerner, J. S., and Keltner, D. (2000), "Beyond Valence: Toward a Model of Emotion-specific Influences on Judgement and Choice. Cognition and Emotion, 14(4): 473-93.

Lerner, J. S., Li, Y., Valdesolo, P. and Kassam, K. S. (2015), "Emotion and Decision Making." Annual Review of Psychology, 66(1): 799-823.

Loewenstein, G. and Lerner, J. S. (2003), "The role of Affect in Decision Making." In Handbook of Affective Science, Richard J Davidson, Klaus R Sherer, and H. Hill Goldsmith, 619-642. Oxford University Press.

Lopes, L. L. (1987), Between Hope and Fear: The Psychology of Risk. Advances in Experimental Social Psychology, 20:255-295.

Merolla, J., Ramakrishnan, S. K., and Haynes, C. (2013), "Illegal," "Undocumented," or

"Unauthorized": Equivalency Frames, Issue Frames, and Public Opinion on Immigration." Perspectives on Politics, 11(3), 789-807.

Miceli, M. S. (2005), Morality Politics vs. Identity Politics: Framing Processes and Competition among Christian Right and Gay Social Movement Organizations. Sociological Forum, 20(4): 589-612.

Nadeau, R., Niemi, R. G., and Levine, J. (1993), Innumeracy about Minority Populations. Public Opinion Quarterly, 57:332-47.

Rodriguez, J. (2007), "Spatial Distribution of the Population, Internal Migration and Development in Latin America and the Caribbean." United Nations Expert Group Meeting on Population Distribution, Urbanization, Internal Migration and Development. http://www.un.org/esa/population/meetings/EG M_PopDist/P06_Rodriguez.pdf

Scheve, K. F. and Slaughter, M. J. (2001), Labor Market Competition and Individual Preferences over
Immigration Policy. The Review of Economics and Statistics, 83 (1): 133-145.

Sides, J. and Citrin, J. (2007), European Opinion About Immigration: The Role of Identities, Interests and Information. British Journal of Political Science, 37: 477504.

Sniderman, P. M., Hougendoorn, L., and Prior, M. (2004), Predispositional Factors and Situational Triggers: Exclusionary Reactions to Immigrant Minorities. American Political Science Review, 98: 35-50.

Zivkovic, T., Warin, M., Davies, M. and Moore, Vivienne. (2010), "In the Name of the Child." Journal of Sociology 46(4): 375-92. 